[Vol. 126:1100

\title{
GOMMENTS
}

\section{LEGAL FEES INCURRED IN LITIGATION INVOLVING TITLE TO ASSETS-ALLOCATION BETWEEN DEDUCTIBLE ORDINARY EXPENSES AND NON- DEDUCTIBLE CAPITAL EXPENDITURES}

The differentiation between deductible and nondeductible expenses under sections 162 and 212 of the Internal Revenue Code ${ }^{1}$ has been a constant and prolific source of controversy. ${ }^{2}$ Perhaps because of the nature of the interested parties, legal expenses constitute a disproportionately large part of this recurring dispute. ${ }^{3}$ Unfortunately, the proper tax treatment of legal fees is very unclear. ${ }^{4}$ Much of the existing uncertainty stems from a myriad of administrative and judicial interpretations that attempt to trace the boundaries of permissible deductions. The taxpayer and his advisor are burdened with reconciling a wealth of interpretive rulings, regulations, and decisions. Congress periodically attempts to dispel the confusion or confirm a particular result by incorporating, qualifying or rejecting the extra-legislative interpretations through amendments to the Code. Congressional intervention usually succeeds only in triggering new rounds of litigation, however.

The history of section $212^{5}$ illustrates this cycle. ${ }^{6}$ In Higgins v. Commissioner, ${ }^{7}$ the Court construed very narrowly the concept

1 References are to the Internal Revenue Code (I.R.C.) of 1954, as amended, unless otherwise noted.

2 See 4A J. Mertens, Law of Feneral Income Taxation $\$ \$ 25.01,25 A .01$ (1972 rev.).

3 The issue promises to remain of current interest to taxpayers as the trend of ever-increasing resort to the courts for the settlement of controversies (and the concomitant rise in overall legal expenditures) shows no signs of abatement. See The Chilling Impact of Litigation, Bus. WEEK, June 6, 1977, at 58 ("litigation hás become the nation's secular religion . . . a virtual epidemic of Thir-trigger suing "); Crisis in Courts-New Moves to Speed Up Justice, U.S. NEws \& WorLD REP., July 18, 1977, at 66 ("the growing tendency of Americans to sue"); Hufstedler, In the Name of Justice-The Unending Rush to the Courts, 43 VITAL SpEeches of THE DAY 572, 575 (1977) ("We have long had the litigating habit, but in recent years, the habit has become an addiction.").

${ }^{4}$ See Note, The Characterization of Legal Fees as Deductible Expenses or Capital Expenditures-A Need for Clarification in the Law, 21 SYRACusE L. REv. 926 (1970). See generally 4A MERTENS, supra note 2, at $\$ \$ 25.01,25 A .01$; McDonald, Deduction of Attorneys' Fees for Federal Income Tax Purposes, 103 U. PA. L. Rev. 168 (1954); Note, The Deductibility of Attorneys' Fees, 74 Harv. L. REv. 1409 (1961).

5 Int. Rev. Code of 1939, ch. 1, $\$ 23(\mathrm{a})(2), 56$ Stat. 819 (now I.R.C. $\$ 212$ ). 6 Int. Rev. Code of 1939, ch. 1, $\$ 23(\mathrm{a})(1), 53$ Stat. 12 (now I.R.C. \$162). 7312 U.S. 212 (1941). 
of "carrying on a business" to exclude management of one's own income producing property, thus denying to the individual deductions available to business taxpayers. Dissatisfied with this construction, Congress added section 23 (a) (2) (current section 212) ${ }^{8}$ to bring the individual into virtual parity with the business taxpayer for this purpose:

[T] he effect of $\$ 23(a)(2)$ was to provide for a class of nonbusiness deductions coextensive with the business deductions allowed by $\$ 23(a)(1)$ [current section 162], except. for the fact that, since they were not incurred in connection with a business, the section made it necessary that they be incurred for the production of income or in the management or conservation of property held for the production of income. ${ }^{9}$

The practical consequence of this parity has been a greatly enlarged opportunity for numerous investors to litigate the propriety of expense deductions. The broad language of sections 162 and 212 provides little guidance for the treatment of expenses in an endless variety of factual contexts. As Justice Cardozo noted: "The Standard set up by the statute is not a rule of law; it is rather a way of life. Life in all its fullness must supply the answer to the riddle." 10 With regard to the deductibility of legal fees incurred in a controversy involving title to assets, the Tax Court is quite correct that "it would be idle to suggest that all the authorities in this field can be reconciled." 11

When legal expenses relate to a controversy involving both capital and ordinary income related elements, current tax tests require a determination of the origin or primary purpose of the underlying controversy and characterize all the expenses as if they stemmed from that single purpose or origin. The present tests, however, are incompatible with the judicial precedents from which they originally derived, and, consequently, have engendered much administrative and judicial confusion. Most importantly, the present tests produce results that do not conform to the federal tax policies underlying the distinction between capital expenditures

8 Revenue Act of 1942, Pub. L. No. 77-753, $\$ 121,56$ Stat. 819.

9 Trust Under the Will of Bingham v. Commissioner, 325 U.S. 365, 374 (1945). See also H.R. ReP. No. 2333, 77 th Cong., 2d Sess. 75 (1942); S. REP. No. 1631, 77th Cong., 2d Sess. 88 (1942).

10 Welch v. Helvering, 290 U.S. 111, 115 (1933).

11 Hermann I. Ruoff, 30 T.C. 204 (1958), rev'd on other grounds, 277 F.2d 222 (3d Cir. 1960), quoted in Woodward v. Commissioner, 397 U.S. 572, 576 (1970). 
and ordinary expenses. This Comment suggests that experience has provided a yet unrecognized workable solution to the riddle of deductibility of legal expenses related to establishing title to assets, and proposes an alternative approach: proportionate allocation of expenses between capital benefits that accrue over an extended period and ordinary benefits that accrue currently.

Section I sets forth the statutory and policy bases of the capitalordinary distinction. Section II presents the problem of the deductibility of the defense expenses and then traces the judicial approaches to distinguishing between ordinary expenses and capital expenditures when title is not directly in issue. Section III explores the shortcomings of the developed tests, and Section IV details the proposed alternative of allocation.

\section{The Statutory Scheme Underlying the Capital- ORDINARY DISTINGTION}

Sections 162 and 212 broadly outline permissible expense deductions. The former allows deduction of all ordinary and necessary business expenses; ${ }^{12}$ the latter permits a corresponding deduction to individuals of all ordinary and necessary expenses incurred for the production or collection of income, or for the management, conservation, or maintenance of income producing property. ${ }^{13}$ Although seemingly irrelevant to the distinction between the capital expenditure and the ordinary expense, section 262, which disallows deduction of personal, living, or family expense, ${ }^{14}$ is also pertinent because of the genesis of the principal test of deductibility.

The Supreme Court has suggested that the differentiation between capital expenditures and ordinary expenses inheres in the "ordinary" standard of sections 162 and 212:

The principal function of the term "ordinary" in $\$ 162$ (a) is to clarify the distinction, often difficult, between those expenses that are currently deductible and those that are

12 "(a) IN GENERAL.-There shall be allowed as a deduction all the ordinary and necessary expenses paid or incurred during the taxable year in carrying on any trade or business .... I.R.C. $\$ 162(a)$.

13 "In the case of an individual, there shall be allowed as a deduction all the ordinary and necessary expenses paid or incurred during the taxable year-

(1) for the production or collection of income;

(2) for the management, conservation, or maintenance of property held for the production of income." I.R.C. \$212.

14 "Except as otherwise expressly provided in this chapter, no deduction shall be allowed for personal, living, or family expenses." I.R.C. \$262. 
in the nature of capital expenditures, which, if deductible at all, must be amortized over the useful life of the assets. ${ }^{15}$

This observation applies equally to the function of the term "ordinary" in section 212. Because of the parallelism of sections 162 and 212, courts have repeatedly indicated that the two provisions "are in pari materia with respect to the capital ordinary distinction." 16

Whether or not the capital-ordinary distinction is implicit in sections 162 and 212, section 263 expressly disallows deduction of capital expenditures. ${ }^{17}$ Generally, this means that expenses otherwise deductible under the Code may not be deducted if "'made primarily for the acquisition, development, or improvement . . . of an asset, interest, or income producing status . . . when either the asset acquired or the benefit derived will last beyond the close of the taxable year." 18 The tax benefit of these capital items is not lost to the taxpayer. Rather, an accounting of these expenditures is either spread over future periods as depreciation deductions ${ }^{10}$ or postponed until the asset is disposed of, in the case of nondepreciable or not fully depreciated assets. ${ }^{20}$ If the asset is not depreciable, the expenditure is credited by a corresponding increase in the basis of the asset under section 1016.

The differentiation between deductible and nondeductible expenses reflects two fundamental policies of matching. First, the Code distinguishes between expenses by the type of endeavor with respect to which they were incurred. As the Supreme Court stated in Lykes v. United States, ${ }^{21}$ "the deductibility [of expenses] turns wholly upon the nature of the activities to which they relate." 22

15 Commissioner v. Tellier, 383 U.S. 687, 689-90 (1966).

16 Woodward v. Commissioner, 397 U.S. 572,575 n.3 (1970). Accord, United States v. Gilmore, 372 U.S. 39,45 (1963); Trust Under the Will of Bingham v. Commissioner, 325 U.S. 365, 373 (1945); Califormia \& Hawaiian Sugar Ref. Corp. v. United States, 311 F.2d 235, 244 (Ct. Cl. 1962).

17 “(a) General RuLE.-No deduction shall be allowed for-

(1) Any amount paid out for new buildings or for permanent improvements or betterments made to increase the value of any property or estate." I.R.C. $\$ 263(\mathrm{a})$.

18 McDonald, supra note 4 , at 172 n.51 (quoting 1 FEDERAx INCOME TAX STATUTE 284, $285 \S \mathrm{X} 166$, Comment (Feb. 1954 draft)).

10 I.R.C. $\$ 167$.

20 "(a) General RoLe.-Proper adjustment in respect of the property shall in all cases be made-

(1) for expenditures, receipts, losses, or other items, properly chargeable to capital account." I.R.C. $\$ 1016(a)$. Although personal expenses are nondeductible under $\$ 262$, see note 14 \& accompanying text, items incurred relative to capital assets held in one's personal capacity, e.g. home improvement expenditures, may increase the basis of those assets under $\$ 1016$.

21343 U.S. 118 (1952).

22 Id. 123 (footnote omitted). 
Under this "categorical" matching, business and investment related expenses are deductible (sections 162 and 212) but personal expenses are not (section 262). Secondly, the Code uses "temporal" matching-the capital-ordinary distinction-to distinguish deductible expenses incurred for the benefit of the contemporaneous income period from nondeductible expenditures incurred for the benefit of future periods. This policy of temporal matching embodied in the capital-ordinary distinction is also manifested in the Code's division of time into twelve month periods ${ }^{23}$ and "the pattern of the revenue laws of accurately matching income and expenses within annual accounting periods." 24 Generally, recognition of income and related deductions of expense should take place in the year or years in which the revenue or expenditure actually benefits the taxpayer. Consequently, "an expenditure should be treated as a non-deductible capital expense if it brings about the acquisition of an asset having a useful life in excess of one year or if the expenditure secures a like advantage to the taxpayer which has a life of more than one year." 25 From the concept of an enduring benefit comes the generally accepted standard for identifying a capital expenditure:

[A] majority of courts have coalesced around what may be denominated an "accrual of benefits" test. That test delimits a standard which holds that a business expenditure is of a capital nature when the benefits of the expenditure are to be enjoyed over a comparatively lengthy period of business operation, usually for a period of greater than the taxable year in question. ${ }^{26}$

The mere existence of a capital element in a particular suit, however, does not automatically determine the deductibility of related expenses. "The rule that legal expenditures are non-deductible when made in connection with certain 'capital' transactions does not mean that, by a Pavlovian reflex, they must always be non-deductible when 'capital' is involved, though the transaction and occasion differ radically." ${ }^{27}$ The lack of any ready touchstone

23 I.R.C. $\$ 441$.

24 Danskin, Inc. v. Commissioner, 331 F.2d 360, 361 (2d Cir. 1964).

25 Clark Oil \& Ref. Corp. v. United States, 473 F.2d 1217, 1219-20 (7th Cir. 1973). Accord, United States v. Mississippi Chem. Corp., 405 U.S. 298, 310 (1972); Medco Prod. Co. v. Commissioner, 523 F.2d 137, 138 (10th Cir. 1975); Georator Corp. v. United States, 485 F.2d 283, 284 (4th Cir. 1973), cert. denied, 417 U.S. 945 (1974).

26 Avery v. United States, 419 F. Supp. 105, 108 (N.D. Iowa 1976).

27 California \& Hawaiian Sugar Ref. Corp. v. United States, 311 F.2d 235, 243 (Ct. Cl. 1962). 
for reliable differentiation has rendered the capital-ordinary distinction particularly troublesome.

\section{The Added Complication of Defense or Perfection of Trtle}

\section{A. The Theory}

Although legal defense of title to a capital asset is clearly analogous to a capital expenditure, the language of section 212 arguably classifies such legal fees as ordinary expenses incurred "for the . . . conservation, or maintenance of property." The Supreme Court has rejected the argument, stating that "in context "conservation of property' seems to refer to operations performed with respect to the property itself, such as safeguarding or upkeep, rather than to a taxpayer's retention of ownership in it." ${ }^{28}$ Indeed, the Regulations provide explicitly that "[e]xpenses paid or incurred' in defending or perfecting title to property ... constitute a part of the cost of the property and are not deductible." 29

This interpretation is consistent with the policy of temporal matching that motivates the capital-ordinary distinction. Title constitutes an asset having a life commensurate with the property to which it attaches. Expenses for defense or perfection of title generate benefits enduring beyond the taxable year in which they are incurred and are therefore capital in nature. ${ }^{30}$ Hence, to the extent that legal expenses are linked to a suit that can be characterized simply as an action to defend or perfect title, they must be capitalized. Conversely, legal fees incurred in a suit that contains no element of title defense or perfection will be deductible if the other requirements of sections 162 or 212 are met.

28 United States v. Gilmore, 372 U.S. 39, 44 (1963) (footnote omitted).

20 Treas. Reg. $\$ 1.212-1(\mathrm{k})$ (1957). See Treas. Reg. $\$ 1.263(\mathrm{a})-2$ (1958) (costs of defending or perfecting title similarly nondeductible under I.R.C. $\$ 263$ ). See cases collected in $4 \mathrm{~A}$ MERTENS, supra note 2 , at $\$ 25.24$ n.43; id. $\$ 25 \mathrm{~A} .16$ n.40.

30 This characterization with respect to defense of title has been criticized "because often the expense, though necessary, adds nothing to the value of the property. The Code $[\$ 263]$ disallows only ; . . any amount paid out . . to to increase the value of any property or estate." McDonald, supra note 4, at 189 (emphasis in original). Courts rarely distinguish title expenses that have failed to increase the value of the underlying asset, probably because of the inherent diffculty of such a determination. But see L. B. Reakirt, 29 B.T.A. 1296, 1297 (1934), affd per curiam, 84 F.2d 996 (6th Cir. 1936). "It is immaterial that this petitioner was required to defend the title long after the property was first acquired, and at a time when he reasonably might have expected to incur no additional title expense." Jones' Estate v. Commissioner, 127 F.2d 231, 232 (5th Cir. 1942). 


\section{B. The Mixed Question}

The capital-ordinary distinction is not so easily applied to litigation expenses incurred in a suit in which defense of title is not directly in issue or is not the sole issue. In Kornhauser $v$. United States, ${ }^{31}$ the Supreme Court recognized that the fact that title to property is in issue does not automatically render legal expenses nondeductible. Just as potential effect on taxpayer's income producing property cannot render otherwise nondeductible expenses deductible, ${ }^{32}$ the mere presence of potential consequences to taxpayer's title cannot render concomitant expenses nondeductible:

In every case where income is derived from the land one may find, lurking somewhere in the background, a question of title to land. Entitlement to income derived directly from the land is directly dependent upon title to the land from which the income was derived. In that broad general sense all income from real estate involves a real estate title. ${ }^{83}$

Denying deduction for the expenses of litigation in which title to assets is only remotely involved, if at all, would render ineffective the mandate of Congress in section 212.34 "It is, with gaze and comprehension foreshortened by a too intense concentration upon the shibboleth of a suit to obtain or defend title, to shut one's eyes" ${ }^{35}$ to reality. An intermediate position is required.

The inequity of an all or nothing approach is demonstrated by the following hypothetical. $A$ and $B$ jointly developed a process for extracting clean burning fuel from coal. At the time, no market for such an energy source existed because the product was relatively more expensive than petroleum fuels. Years later, $B$ discovers that $A$ has patented the process in $A$ 's name alone and has granted licenses for its use in return for substantial royalties. $B$ approaches $A$ and reminds him of the genesis of the process and demands a share of past and future royalties. $A$ flatly refuses, claiming that the patent belongs to him alone. $B$ consults an attorney and files suit, requesting a declaration of his interest in the patent and an

31276 U.S. 145 ( 1928 ).

32 Lykes v. United States, 343 U.S. 118, 125 (1952). See text accompanying notes 57-64 infra.

33 Usry v. Price, 325 F.2d 657, 659 (5th Cir. 1963).

${ }^{34}$ Sergievsky v. McNamara, 135 F. Supp. 233, 238 (S.D.N.Y. 1955).

35 Allen v. Selig, 200 F.2d 487, 489 (5th Cir. 1952). 
accounting for past revenue. $B$ 's suit is successful. The court declares his ownership of a one-half interest in the patent and orders $A$ to account for revenues already collected. $B$ collects $\$ 75,000$ in accrued royalties and his future interest in the patent is appraised at $\$ 225,000$. In litigating the issues and obtaining the payment, $B$ incurred $\$ 4000$ in legal fees. What is the proper tax treatment of this expense item?

A mechanical answer categorizing all the expenses as capital or ordinary ignores the realities of the underlying transaction, and is undeniably inequitable. $B$ 's suit had two purposes or origins: to obtain declaration of his interest in the patent and to recover past royalties. The two major judicial tests for classifying legal expenses as capital or ordinary assume, however, that each suit has only one true purpose ${ }^{36}$ or origin. ${ }^{37}$ Thus, under current doctrine a court might classify $B$ 's expenses entirely as nondeductible capital expenditures, if it determines as a factual matter that perfection of his title to an interest in the patent was $B$ 's primary purpose or that the patent (a capital asset) lay at the origin of his claim. This outcome is inequitable in that it penalizes $B$ with nondeductibility of his entire legal expenditure merely because his suit furthered several purposes or derived from several origins. In remarks concerning the primary purpose test, one court frankly admitted the inferiority of the monolithic approach: "Divining the primary purpose of the surveys here is beyond our competence. Nor do we perceive that all human conduct must necessarily have one primary or principal motivation. In fact the more 'principal' purposes a venture has, the more desirable it may be." 38 Courts clearly lack a principled basis for holding that one element of an action with multiple origins or purposes so predominates all others that the entire expense is attributable to it.

Most importantly, however, an all or nothing result does not comport with the fundamental policy of temporal matching of deduction and corresponding income. If all $B$ 's expenses are are deemed capital, they will be applied entirely to increase his basis in the patent for later depreciation or determination of gain or loss on ultimate disposition. $B$, however, has received $\$ 75,000$ in current income against which he will have no current deduc-

36 See, e.g., Rassenfoss v. Commissioner, 158 F.2d 764, 767 (7th Cir. 1946).

37 See, e.g., United States v. Hilton Hotels Corp., 397 U.S. 580 (1970); Woodward v. Commissioner, 397 U.S. 572 (1970); United States v. Gilmore, 372 U.S. 39 (1963).

38 Rust-Oleum Corp. v. United States, 280 F. Supp. 796, 801 (N.D. Ill. 1967). 
tion. ${ }^{39}$ To the extent that a portion of the expenses were attributable to the collection of that income, he has been denied the benefit of their deduction. Alternatively, if all of the expenses are considered ordinary, $B$ will have the benefit of windfall deductions to the extent any of the expenses were actually attributable to perfection of title to his patent interest and should have been spread over the life of the patent.

\section{The Judicial Tests}

Obviously some alternative analysis is necessary to alleviate the shortcomings of the present tests. Consequently, closer examination of these tests is necessary to set the performance standards for a substitute mechanism.

\section{The Primary Purpose Test}

The first test developed by the courts for distinguishing capital from ordinary legal expenditures was the primary purpose test. Under this standard, the primary purpose of the litigation controls the deductibility of the accompanying expenses:

[I]f the primary or sole purpose of the suit is to protect or defend title, the expenditures are not deductible. ... On the other hand, even though title may be involved, if its defense or perfection is not the primary purpose of the litigation, the expenditures do not encounter the barrier of the regulation's standard and they may qualify instead as ordinary and necessary expenses. ${ }^{40}$

Thus expenditures that would otherwise be considered capital become deductible when combined with a stronger noncapital purpose. "The primary purpose rule ... involves looking at a transaction and determining ... whether the additional transactions, although when viewed separately might in themselves look different, are necessary concomitants to the primary or dominant aspect." 41

The test was originally formulated in Rassenfoss v. Commissioner, $^{42}$ in which the taxpayer, a partner, had defended against

39 Of course, $B$ would be forced to recognize all of the income currently without the benefit of a deduction had he in fact incurred no related expenses. Furthermore, income averaging, I.R.C. $\$ \$ 1301-05$, may be available to $B$. 1960).

40 Industrial Aggregate Co. v. United States, 284 F.2d 639, 645 (8th Cir.

41 Buder v. United States, 221 F. Supp. 425, 429 (E.D. Mo. 1963).

42158 F.2d 764 (7th Cir. 1946). 
the partnership superintendant's demand that he be declared a partner and that there be an accounting of partnership revenue and assets. The court acknowledged that "the line of demarcation between an 'ordinary and necessary expense' as a deductible item and an expenditure incurred in defense of title to property and therefore not deductible is extremely narrow." 43 Forced to decide the issue on the facts before it, the court held: "[I]t is perfectly plain, so we think, that the main and primary purpose of the suit which petitioner defended was for an accounting and any question of title was merely incidental thereto." 44 By its own admission, the court in Rassenfoss was strongly influenced by the apparent frivolity of the claim that resulted in the original complainant's being granted a $1.75 \%$ limited partnership interest. ${ }^{45}$

The primary purpose test was amplified by Industrial Aggregate Co. $v$. United States, ${ }^{46}$ in which the taxpayer, engaged in the business of removing sand, gravel, and other materials from leased land, had been sued by his lessor for breach of the underlying leases. The Eighth Circuit found that even though title had been involved, the primary purpose of the lessor in the original litigation was to recover damages and that the taxpayer's primary purpose was to resist such liability. ${ }^{47}$ Hence, it held the taxpayer's legal expenses to be entirely deductible. In its determination of the governing purpose, the court looked to the pleadings, the evidence, the stipulation for settlement, the opponent's purpose in instituting suit, the taxpayer's purpose in defending, and each party's purpose in settling. ${ }^{48}$

The primary purpose test has also been utilized to deny taxpayers' deductions under similar fact situations. ${ }^{49}$ For example, in

$48 I d .766$.

44 Id. 767 .

45 Id. The court referred to the limited partmership interest as "almost an infinitesimal .... interest in the partnership." Id.

46284 F.2d 639 (8th Cir. 1960). See text accompanying note 41 supra.

47284 F.2d at 647 .

$48 \mathrm{Id}$. In a similar case involving a declaration of partnership interest and an accounting, the court in Marsh v. Squire, 48-1 U.S. Tax Cas. T9142 (W.D. Wash. 1947), concluded that the suit brought by a former partner who had disappeared twenty years before, was brought primarily for an accounting and receivership and only incidentally for a decree vesting in him a specific interest in the property. Therefore, all of the expenses incurred by the taxpayer in defending the suit were held to be deductible.

40 Lewis v. Commissioner, 253 F.2d 821 (2d Cir. 1958); Addison v. Commissioner, 177 F.2d 521 (8th Cir. 1949); Safety Tube Corp. v. Commissioner, 168 F.2d 787 (6th Cir. 1948); Boulder Building Corp. v. United States, 125 F. Supp. 512 (W.D. Okla. 1954); Kasey v. Commissioner, 54 T.C. 1642 (1970), affd, 457 F.2d 369 (9th Cir.), cert. denied, 409 U.S. 869 (1972). 
Kasey v. Commissioner, ${ }^{50}$ a suit for recovery of mining property and for an accounting, the Tax Court held that "[p]etitioner's right to receive an accounting or damages was wholly dependent upon and incident to the resolution of the primary issue, viz, the determination of title, and it is clear that the litigation concerned exclusively this issue." 51 The expenses were therefore completely nondeductible. Similarly, in Safety Tube Corp. $v$. Commissioner, ${ }^{52}$ the Sixth Circuit concluded that legal expenses involved in a suit for declaration of title to a patent and for an accounting were fully nondeductible:

The suit clearly involved the title to the Bradley patent as a principal issue and the accounting for royalties as held by the Tax Court was only a corollary to the determination of rights under the patent. The gist of the controversy is the right to the asset which produced the income. If the Bradley patent belonged to Seaton, then obviously the petitioner was not entitled to royalties. . . . [T] he litigation here struck at the very ownership of the patent itself. ${ }^{53}$

The primary purpose test may be criticized in several respects. First, as the cases described demonstrate, the standard yields "all or nothing" results. All of the expenses incurred become either deductible or nondeductible, depending on the court's determination of the taxpayer's primary purpose or intent. ${ }^{54}$ Second, the primary purpose test necessarily involves courts in a difficult determination of the taxpayer's subjective intent. ${ }^{55}$ The use of the pur-

5054 T.C. 1642 (1970).

51 Id. 1649.

52168 F.2d 787 (6th Cir. 1948).

53 Id. 790.

54 Undeniably inequitable results follow when, for example, the taxpayer conducts litigation with mixed motives. When a taxpayer recovers an asset that will benefit him for a period greater than one year and items constituting current income, his intent should be irrelevant. Rather, the policy of temporal matching of deductions with corresponding income points towards allocation of expenses between capital and ordinary classifications as the theoretically sound outcome.

55 Difficult of reliable proof and potentially as varied as the individuals to which it is ascribed, intent has been rejected or criticized in numerous contexts when proposed as an appropriate standard. See Blum, Motive, Intent, and Purpose in Federal Income Taxation, 34 U. Cen. L. REv. 485 (1967). The Supreme Court has ruled out use of the primary purpose test for determination of the deductibility of legal expenses incurred in the "process of acquisition" of assets, stating: "A test based upon the taxpayer's 'purpose' in undertaking or defending a particular piece of litigation would encourage resort to formalisms and artificial distinctions." Woodward v. Commissioner, 397 U.S. 572, 577 (1970). See text accompanying notes 83-84 supra. 
pose standard often leads to capricious results where one taxpayer may deduct all his expenses while another must capitalize all his expenses even though the underlying disputes are analogous. ${ }^{56}$ As a corollary, the intent standard undermines the element of certainty so necessary to the revenue laws.

\section{The Origin of the Claim Test}

This more recently developed standard requires an objective determination of the origin of the claim with respect to which the expenses were incurred rather than the determination of the subjective intent or purpose of the taxpayer in instituting or defending suit. The rule itself, however, was intended to distinguish between the origin of a particular legal action and the consequences which that same action may have on the business or income producing assets of the taxpayer. Previously, taxpayers had attempted to escape disallowance of personal expense deductions by arguing that the predecessors of sections 162 and 212 allowed deduction of legal expenses incurred to avert potential consequences to business and income producing property. The argument with respect to income producing property reached the Supreme Court first.

In Lykes $v$. United States, ${ }^{57}$ the Court held legal expenses nondeductible if incurred in contesting liability for gift tax.58 To counter the argument that expenses related to the essentially personal activity of gift-giving were nondeductible, the taxpayer in that case contended that to pay the tax originally assessed he would have been forced to liquidate stock thereby cutting off his major source of income. Therefore, he argued, his legal expenses were deductible under section 212's predecessor because they were incurred to conserve income producing property. ${ }^{59}$ Noting that the "deductibility [of legal expenses] turns wholly upon the nature of the activities to which they relate," 80 the Court rejected the taxpayer's argument:

56 Compare Sergievsky v. McNamara, 135 F. Supp. 233 (S.D.N.Y. 1955) and Allen v. Selig, 200 F.2d 487 (5th Cir. 1952) with Lewis v. Commissioner, 253 F.2d 821 (2d Cir. 1958) and Garrett v. Crenshaw, 196 F.2d 185 (4th Cir. 1952). See also text accompanying notes 46-53 supra.

57343 U.S. 118 (1952).

58 Congress has overturned this result in the 1954 Code. I.R.C. $\$ 212(3)$.

59 Alternatively, the taxpayer argued that the distributions of stock to his children were not subsumed within the personal activity of gift-giving because they were, rather, "part of a general plan to produce income for himself," being in the nature of distributions pursuant to a stock-incentive plan for key employees of the closely-held business of which taxpayer was a major shareholder. This characterization was rejected as lacking factual support. 343 U.S. at 123-24.

60 Id. 123. 
Legal expenses do not become deductible merely because they are paid for services which relieve a taxpayer of liability. That argument would carry us too far. It would mean that the expense of defending almost any claim would be deductible by a taxpayer on the ground that such defense was made to help him keep clear of liens whatever income-producing property he might have.

If, as suggested, the relative size of each claim, in proportion to the income-producing resources of a defendant, were to be a touchstone of the deductibility of the expense of resisting the claim, substantial uncertainty and inequity would inhere in the rule. ... It is not a ground for . . . [deduction] that the claim, if justified, will consume income-producing property of the defendant. ${ }^{61}$

The rationale underlying Lykes is clear: the deductibility of expenses should not rest on the potential effect a judgment will have on the income producing property or business assets of a taxpayer.

The phrase "origin of the claim," which does not appear in the Lykes opinion, has come to be associated with United States $v$. Gilmore..$^{62}$ In that case the Court held that legal fees incurred to avoid potential consequences to business (as contrasted from investment, the issue presented in Lykes) do not qualify for deduction under section 162's predecessor, if the origin of the expenses is a personal transaction. The taxpayer, Gilmore, had incurred substantial legal fees in defending a divorce action. ${ }^{63}$ The taxpayer claimed deduction of his legal expenses attributable to the successful resistance of his former wife's community property claims, which, had she prevailed, would have severely impaired his ability to earn his living. ${ }^{64}$ The Supreme Court accepted the Court of Claims determination that the taxpayer's "overriding concern" was to protect his business related assets, ${ }^{65}$ but determined that all his expenses were nondeductible personal expenditures:

61 Id. 125-26.

62372 U.S. 39 (1963). The phrase did appear in prior Supreme Court opinions. See, e.g., Interstate Transit Lines v. Commissioner, 319 U.S. 590 (1943); Deputy v. du Pont, 308 U.S. 488 (1940).

63 Gilmore v. Gilmore, 45 Cal. 2d 142, 287 P.2d 769 (1955).

64 The assets consisted primarily of controlling interests in three General Motors automobile dealerships from which be received virtually his entire income. United States v. Gilmore, 372 U.S. 39, 41 (1963).

65 Id. 
The principle we derive from these cases is that the characterization, as "business" or "personal," of the litigation costs of resisting a claim depends on whether or not the claim arises in connection with the taxpayer's profitseeking activities. It does not depend on the consequences that might result to a taxpayer's income-producing property from a failure to defeat the claim, for, as Lykes teaches, that "would carry us too far" ....

... [T]he origin and character of the claim with respect to which an expense was incurred, rather than its potential consequences upon the fortunes of the taxpayer, is the controlling basic test . . . ${ }^{86}$

Under the facts of the case, the Supreme Court held the expenses entirely nondeductible because "the wife's claims stemmed entirely from the marital relationship, and not, under any tenable view of things, from income-producing activity." 67

The concerns that motivated the Lykes and Gilmore decisions were twofold: (1) taxpayers should not be permitted to bring their expenses within sections 162 and 212 artificially and without sufficiently close relation to the profit-seeking bases of those provisions, and (2) differential treatment should not be accorded taxpayers based on the makeup of their assets. A system would hardly be rational that granted a deduction to the taxpayer whose legal expenses in personal injury litigation were to be satisfied out of stockholdings while denying a deduction to the taxpayer who was

66 Id. 48-49 (footnotes omitted).

67 Id. 51. In Gilmore's companion case, United States v. Patrick, 372 U.S. 53 (1963), the Court similarly held that "the claims asserted by the wife in the divorce action arose from respondent's marital relationship with her and were thus the product of respondent's personal or family life, not profit-seeking activity." Id. 56. The taxpayer had based his deduction on the theory that the fees were incurred in order to arrange the property settlement so that his income producing property would not be affected.

Having decided the categorical matching issue, the Gilmore Court left open the temporal matching issue of whether the legal expenses, although not currently deductible because personal, were, nonetheless, capitalizable into the basis of Gilmore's stock:

In view of this conclusion [that the expenses are personal] it is unnecessary to consider the further question suggested by the Government: whether that portion of respondent's payments attributable to litigating the issue of the existence of community property was a capital expenditure or a personal expense. In neither event would these payments be deductible from gross income.

372 U.S. at 52 . See also note 20 supra \& accompanying text. Indeed, a subsequent district court decision held capitalization of the expenses into the stock basis to be proper. Gilmore v. United States, 245 F. Supp. 383 (N.D. Cal. 1965). 
forced to sell his home in order to satisfy the judgment against him. "We should be slow to attribute to Congress a purpose producing such unequal treatment among taxpayers, resting on no rational foundation." 88

Seven years after Gilmore, the Supreme Court in two companion cases, Woodward $v$. Commissioner ${ }^{69}$ and United States $\nu$. Filton Hotels Corp.,$^{70}$ applied the origin of the claim test, not, as in Lykes and Gilmore, to decide the categorical matching issue, but rather to determine the temporal matching issue of distinguishing capital from current expenses. In Woodward, the principal case, the taxpayers, majority shareholders of an Iowa corporation, voted for perpetual extension of the corporate existence. Under Iowa law, they were forced to purchase the stock of the dissenting minority shareholder at its real value. ${ }^{71}$ When the parties failed to agree upon an appropriate price, the taxpayers brought an appraisal action that ended in a determination of the selling price by the Iowa Supreme Court. ${ }^{72}$ The taxpayers incurred extensive legal, appraisal, and accounting fees for which they claimed deductions as ordinary and necessary expenses under section 212. The single question involved was whether these expenses were non-deductible as capital expenditures incurred in the process of acquiring the stock, without regard to the business-personal distinction of Gilmore and without the added complication of title defense or perfection.

The taxpayers attempted to import the primary purpose test from the defense or perfection of title cases, but the Supreme Court rebuffed the effort:

[T] he "primary purpose" test has no application here. That uncertain and difficult test may be the best that can be devised to determine the tax treatment of costs incurred in litigation that may affect a taxpayer's title to property more or less indirectly, and that thus calls for a judgment whether the taxpayer can fairly be said to be "defending or perfecting title." Such uncertainty is not called for in applying the regulation that makes the "cost of acquisition" of a capital asset a capital expense ... [which] in-

68372 U.S. at 48 . The example is one suggested by the Court in Gilmore. Id. 69397 U.S. 572 (1970).

70397 U.S. 580 (1970).

71 Iowa Code Ann. $\$ 491.25$ (West Cum. Supp. 1977-78).

72 Woodward v. Quigley, 257 Iowa 1077, 133 N.W.2d 38, modified on rehearing, 257 Iowa 1104, 136 N.W.2d 280 (1965). 
volves the simpler inquiry whether the origin of the claim litigated is in the process of acquisition itself. ${ }^{73}$

Applying this theory to the Woodward facts, the Court held the expenses to be nondeductible capital expenditures because "[w] here property is acquired by purchase, nothing is more clearly part of the process of acquisition than the establishment of a purchase price." 74

The slightly different factual setting of Woodward's companion case, United States $v$. Hilton Hotels Corp..$^{75}$ raised essentially the same legal issue only in this instance under section 162 rather than section 212. Hilton Hotels Corporation, the taxpayer, which owned almost ninety percent of the common stock of the Hotel WaldorfAstoria Corporation, decided to merge the two companies. The holders of approximately six percent of the Waldorf stock objected to the merger and demanded payment for their stock under the applicable New York statute. Rejecting Hilton's cash offer, the dissenters began appraisal proceedings in connection with which Hilton incurred legal and other professional service fees. On the strength of its decision in Woodward, the Supreme Court held the expenses nondeductible because "expenses of litigation that arise out of the acquisition of a capital asset are capital expenses." 70 The Court found it immaterial that by operation of New York law title to the dissenters' stock passed to Waldorf as soon as they indicated their dissent, ${ }^{77}$ because the determination of price is an integral part of the acquisition process. ${ }^{78}$ The Court rejected the Seventh Circuit's use of the primary purpose test in order to determine the nature of expenses incurred in the acquisition of capital assets. 79

Three aspects of the Woodward and Hilton Hotels holdings should be emphasized. First, although the Court invoked Gilmore as authority for applying the origin of the claim test, ${ }^{80}$ Gilmore, as already noted, employed the test in determining the entirely distinct categorical issue. Indeed, courts in the period between Gilmore and Woodward had frequently recognized the limited nature of the

73 Woodward v. Commissioner, 397 U.S. 572, 577 (1970).

74 Id. 579 (footnote omitted).

75397 U.S. 580 (1970).

76 Id. 583.

77 Id. 584.

78 Id.

79 Id. 583.

so [A] standard based on the origin of the claim comports with this Court's recent ruling in [Gilmore]." Woodward v. Commissioner, 397 U.S. 572, 578 (1970). 
origin inquiry and indicated that the Gilmore test was unsuited to the capital-ordinary inquiry. The court in Vermont Bank b Trust Co. v. United States ${ }^{81}$ concluded: "The question is not, as in Gilmore, whether the expenses were personal or business in nature but instead whether the expenses must be capitalized. It is the Court's conclusion that the Gilmore test has no application to the latter question." 82

Second, the Court specifically limited its holdings in Woodward and Filton Hotels to cases where legal fees are expended incident to the "process of acquisition." ${ }^{83}$ The Court acknowledged the continuing applicability of the primary purpose test for purposes of distinguishing capital and ordinary expenses in defense or perfection of title cases: "[The primary purpose] test may be the best that can be devised to determine the tax treatment of costs incurred in litigation that may affect a taxpayer's title more or less indirectly, and that thus calls for a judgment whether the taxpayer can fairly be said to be "defending or perfecting title." " 84

81296 F. Supp. 682 (D. Vt. 1969).

82 Id. 685. See also Beerman v. United States, 390 F. 2d 638 (6th Cir. 1968); Powell v. United States, 294 F. Supp. 977 (D.S.D. 1969), rev'd sub nom. Helgerson v. United States, 426 F.2d 1293 (8th Cir. 1970); Mitchell v. United States, 408 F.2d 435 (Ct. Cl. 1969).

A district court opinion and subsequent court of appeals reversal provide an instructive comparison of the disparate resuits of the two origins tests. In Powell v. United States the taxpayers incurred legal expenses in suits arising from a complicated transaction involving an option to acquire the taxpayers' stock in a life insurance company (National). The state insurance commissioner took custody of the stock, which taxpayers had placed in escrow as security pursuant to the option and purchase agreement, in order to prevent the contemplated acquisition. Taxpayers instituted a class action on behalf of National's stockholders against the prospective purchaser to preserve the value of their stock. The government stipulated that none of the legal expenses were incurred because of the negotiation for the option and purchase agreement of the original sale. The lower court held the expenses deductible under section 212.

The stock, the value of which the taxpayers attempted to conserve through the discussed litigation, represented the controlling interest of National. Certainly it cannot be argued that that litigation was not an attempt to conserve property held for the production of income. . . Clearly the present case meets the [business origin] test as required $\dot{b} \dot{y}$ Gilmore.

294 F. Supp. at 978. After the Woodward and Hilton Hotels decisions, the court of appeals reversed the lower court: "We conclude from the record and the stipulated facts that the attorneys' fees and expenses originated in the process of disposition of the controlling stock interest in National, and hence are not deductible by appellees under $\$ 212 . "$ Helgerson, 426 F.2d at 1297 . The two decisions starkly reflect the differences in the two origin tests, the district court holding the expenses deductible because of their business origin and the court of appeals holding the expenses nondeductible because of their sale origin.

83 The Court cited approvingly Treas. Reg. $\$ 1.263(\mathrm{a})-2(\mathrm{a})$ (1958) (" ' $[T]$ he cost of acquisition ... of ... property having a useful life substantially beyond the taxable year is a capital expenditure."). 397 U.S. at 575-76.

84 Id. 577. 
Third, Woodward and Hilton Hotels involved extremely simple issues and were ill-suited to the highest court's announcement of a test that would be used by lower courts to resolve a whole range of subsequent cases. The Supreme Court recognized that Woodward was not a borderline case in which characterization of the expenses as acquisition related might present difficulty. ${ }^{85}$ The court proceedings underlying both cases consisted of setting the price at which stock would be purchased by the taxpayers. Undeniably, the determination of the price is an essential ingredient' in the acquisition of any asset: "Under whatever test might be applied, such expenses would have clearly been 'part of the acquisition cost' of the stock." 88

Even under the "uncertain and difficult" primary purpose test, neither taxpayer should have been able to establish the deductibility of the expenses involved. As the appeals court found in Woodward, in such a suit the only credible purpose, setting the price of the stock, was "inextricably woven into the fabric" 87 of a capital transaction. Similarly in Hilton Hotels the Seventh Circuit explicitly found that "the paramount purpose of the appraisal proceeding was to determine the fair value of the dissenting stockholders' shares in Waldorf." ss Under any reasonable interpretation of the primary purpose test, such a finding should have been fatal to the taxpayers' deductibility claim. Actually, however, the Seventh Circuit was able to divorce the setting of the price from the process of acquisition and held the expenses deductible because under the New York statute title to the dissenters' stock passed as soon as they indicated their dissent. 89

Further, in Woodward, the principal case, the taxpayers' actual theory for deductibility under section 212 was extremely weak, thus presenting the Court with no tenable opposing theory to consider. The taxpayers claimed that their expenses were incurred for the management, conservation, or maintenance of income producing property. As the Eighth Circuit expressed it:

[P] etitioners suggest that [the property conserved] was their cash; that is to say, the less money the petitioners had to pay for the stock the more money they would conserve.

85 Id. 578-79.

86 Id. 578.

87 Woodward v. Commissioner, 410 F.2d 313, 320 (8th Cir. 1969), affd, 397 U.S. 572 (1970).

88 Hilton Hotels Corp. v. United States, 410 F.2d 194, 197 (7th Cir. 1969), rev'd, 397 U.S. 580 (1970). 
This contention is wholly without substance. Section 212 was not designed to allow tax deductions for the preservation of one's net worth..$^{90}$

The taxpayers' argument was simply an extension of the claim rejected in Lykes $\boldsymbol{v}$. United States, ${ }^{91}$ that the potential consequences of a particular action on income producing property control the deductibility of the expenses so incurred regardless of the nature of the underlying controversy. Finally, because of the factual similarity with Woodward and the peculiar New York statutory provision upon which the Seventh Circuit hinged its decision, the Supreme Court was able to reverse the court of appeals in Hilton Hotels without additional theoretical discussion of the correct test.

The Woodward and Hilton Hotels decisions reached correct results on their facts, but were based on a hasty adoption of the origin of the claim test, a test developed for the resolution of an entirely separate issue. Given their factual simplicity they were poorly chosen vehicles for the promulgation of the new test. The Court may be criticized for its failure to recognize the latent dysfunction of the origin of the claim test in the capital-ordinary area. In the context of the simple setting in which the test was adopted, the lack of foresight is understandable; the ensuing uncritical extension by the lower federal courts of the origin test to the more complex areas of the capital-ordinary distinction is not.

The origin test was quickly adopted by the lower courts to classify expenditures as capital in the analogous area of disposition of property. ${ }^{92}$ The courts also utilized the test to distinguish capital expenditures from deductible expenses in a variety of litigation, including trademark infringement, ${ }^{93}$ condemnation proceedings, ${ }^{94}$ corporate liquidation under section 337,95 appraisal proceedings in merger acquisition, ${ }^{96}$ nuisance action against adjoining land-

90410 F.2d at 318.

91343 U.S. 118 (1952).

92 Estate of Baier v. Commissioner, 533 F.2d 117, 120 (3d Cir. 1976) ("We are satisfied that the "origin of the claim test" applies to expenses incident to the disposition of property, as well as to the acquisition of property."); Estate of Meade v. Commissioner, 489 F.2d 161 (5th Cir.), cert. denied, 419 U.S. 882 (1974); Helgerson v. United States, 426 F.2d 1293 (8th Cir. 1970); Munn v. United States, 455 F.2d 1028 (Ct. Cl. 1972).

93 Medco Prod. Co. v. Commissioner, 523 F.2d 137 (10th Cir. 1975).

94 Madden v. Commissioner, 514 F.2d 1149 (9th Cir. 1975), cert. denied, 424 U.S. 912 (1976).

95 See Of Course, Inc. v. Commissioner, 499 F.2d 754 (4th Cir. 1974).

96 Third Nat'l Bank v. United States, 427 F.2d 343 (6th Cir. 1970). 
owner, ${ }^{97}$ civil antitrust claim, ${ }^{98}$ contract action to rescind purchase order for stock, ${ }^{99}$ and stockholders' derivative suits based on malfeasance by management ${ }^{100}$ and on fraud by a family member in a close corporation. ${ }^{101}$

The most significant extension of the origin of the claim test for purposes of the present inquiry has been to the area of defense or perfection of title. The applicability of the origin test to defense of title cases was first intimated in dicta of the Seventh Gircuit's opinion in Anchor Coupling Co. v. United States. ${ }^{102}$ Negotiations for the sale of the taxpayer corporation were aborted by one of the corporation's two major shareholders. The potential purchaser filed suit alleging that the negotiations constituted a contract for the sale of Anchor's assets and sought specific performance. A settlement was reached in which Anchor paid $\$ 600,000$, which it deducted from its gross income under section 162. The court held the expenses nondeductible because " $[t]$ he origin and nature of the claim by Borg-Warner, which was liquidated by Anchor's settlement payment, directly concerns Anchor's capital assets." 103

Anchor had argued for deductibility on the ground that its purpose in settling was to eliminate the stultifying impact of the litigation on its business operations. The court, however, refused to follow Rassenfoss $v$. Commissioner ${ }^{104}$ and other cases applying the primary purpose test, ${ }^{105}$ because it understood that test to be no longer applicable to the facts before it in light of the Supreme Court's decisions in Woodward and Hilton Hotels. Although defense or perfection of title was not involved in Anchor Coupling, the Seventh Circuit purported to analyze the case as if it were: "Anchor protected ownership to its assets by removing Borg-Warner's claim through the settlement payment of $\$ 600,000 . " 108$ In dicta it interpreted Woodward and Hilton Hotels as justifying abandonment of the primary purpose test for the determination

97 Clark Oil \& Ref. Corp. v. United States, 473 F.2d 1217, 1220 (7th Cir. 1973) ("The acquisition of this property was at the heart of the dispute.").

98 Estate of Meade v. Commissioner, 489 F.2d 161 (5th Cir.), cert. denied, 419 U.S. 882 (1974).

99 Cf. Meyer v. Commissioner, 547 F.2d 943 (5th Cir. 1977), discussed at note 126 infra. 1976).

100 Newark Morning Ledger Co. v. United States, 539 F.2d 929 (3d Cir.

101 Brown v. United States, 526 F.2d 135 (6th Cir. 1975).

102427 F.2d 429 (7th Cir. 1970), cert. denied, 401 U.S. 908 (1971).

103 Id. 433.

104158 F.2d 764 (7th Cir. 1946).

105427 F.2d at 434 .

106 Id. 433. 
of the deductibility of incidental expenses even where protection of ownership (as contrasted from acquisition of property) is the underlying transaction:

[T] he Court did not intimate the extent to which the primary purpose test, as applied to costs incurred in protecting ownership, has been rejected by the adoption of an objective standard of deductibility in Gilmore and Woodward. We are convinced that the considerations which prompted the Court to announce such a test in these cases also impel us to fashion a similar test for determining whether the settlement payment in this case is a business expense or a capital expenditure. ${ }^{107}$

This interpretation is wholly unwarranted given the Supreme Court's express limitation of its Woodward holding to acquisition cases. ${ }^{108}$ In any event, the gratuitous nature of the quoted portion of Anchor Coupling is easily demonstrated. The court could have denied the deduction for the expenses regardless of the test employed. The origin of the Borg-Warner claim, specific performance of an alleged contract for sale, was as certainly "in the process of acquisition" as the stock appraisals in Woodward and Hilton Hotels. The primary purpose of the settlement was to rid the company of a claim against the entirety of its assets, a capital concern, which had resulted incidentally in stagnant sales and income. Failing to establish the expenses' deductibility under either of these standards, the company also failed to meet the fundamental test of a capital expenditure: Anchor acquired a benefit that would last beyond the taxable year. Under any test, therefore, the expenses were capital.

Furthermore, title, in the sense used in previous decisions, was simply not in issue in Anchor Coupling. The substance of the suit against Anchor was a contract, not an ownership claim, albeit a contract claim for specific performance of an agreement to sell-to transfer title to-the assets. ${ }^{109}$ The defense of title cases in which the primary purpose test has traditionally been used have uniformly involved expenses growing out of litigation of ownership-not contract-issues. The court simply overstepped the boundaries of good judgment and erred in holding that the origin of the claim test had superseded the primary purpose test in the title area. Such a determination was unnecessary to its decision.

107 Id. 432-33.

108 See text accompanying notes 83-84 supra.

109 In order to characterize the suit as sounding in property rather than contract, the court invoked the "doctrine of equitable conversion." Id. 433. 
The Anchor Coupling dicta was cited and followed by the Tax Court in Reed $v$. Commissioner, ${ }^{110}$ a case actually presenting a defense of title issue. Taxpayer, as beneficiary of her mother's will, filed suit against the mother's former partners in a food enterprise. In the first cause of action, the taxpayer sought to have a constructive trust, preliminary to a reconveyance, imposed on what had been her deceased father's interest in the same partnership; taxpayer's mother, while still alive, had had the option to purchase this interest. Taxpayer alleged that the defendants (the other partners) had acquired the father's interest through a breach of fiduciary duty owed the mother. In the second cause of action, taxpayer sought rescission of that part of the partnership agreement that imposed restrictions on the free transferability of what had been the mother's interest in the partnership. She alleged that these restrictions had been obtained unfairly by preying on the mother's incompetency. The court denied the taxpayer's claim to deductions for legal expenses under sections 162 and 212 on the basis of the origin of the claim test. ${ }^{111}$ The first cause of action fits neatly into the Woodward and Hilton Hotels "process of acquisition" category; thus application of the origin test to its expenses was appropriate. The court characterized the second cause of action, however, as having the elements of a suit to perfect or quiet title, which, because of substantial restrictions on transferability, was incomplete. ${ }^{112}$ Applying the origin test on the strength of Woodward as interpreted in the Anchor Coupling dicta, the court held that the origin of the suit was "directly related to the capital asset underlying the partnership agreement, hence the expenditures were capital in nature." 113

Without quarreling with Reed's result, the uncritical acceptance of the Seventh Circuit's dicta is disturbing. The danger of the Anchor Coupling test is that all title defense or perfection related expenses will be deemed capital because any suit to defend or perfect title will have a capital asset at its origin. Certainly decision by "Pavlovian reflex" 114 or by "concentration on the shibboleth of a suit to perfect or defend title" ${ }^{115}$ cannot have been the

11055 T.C. 32 (1970).

111 As the Tax Court observed, the same result of nondeductibility of the expenses attendant to the second cause of action would have been reached under the primary purpose test. Id. $41 \mathrm{n} .12$.

112 Id. 41,42 .

113 Id. 42.

114 California \& Hawaiian Sugar Ref. Corp. v. United States, 311 F.2d 235, 243 (Ct. Cl. 1962).

11 J Allen v. Selig, 200 F.2d 487, 489 (5th Cir. 1952). 
intended result of Supreme Court adoption of the origin of the claim test in Woodward and Hilton Hotels. Certainty of result may have been achieved but at the expense of realistic examination of the facts of a particular controversy.

\section{The Mixed Question In the Dual Nature Litigation:} An Example of the Dysfunction of the Developed Tests

Consider the tax consequences to the hypothetical taxpayer $\dot{B}^{116}$ when the two principal judicial tests are applied. A court applying the primary purpose test would look to a host of indicia of the taxpayer's subjective intent in litigating the suit, ${ }^{117}$ and, according to its determination of which purpose-to obtain an accounting of past revenue or to obtain a declaration of entitlement to an interest in the patent-was dominant, hold the legal expenses deductible or nondeductible.

Application of the Gilmore origin of the claim test results in the simple determination that the expenses here were not personal but arose in a profit-seeking context. The source of the controversy lay in $B$ 's trade or business as an inventor, not in any personal or non-profit-seeking endeavor. Once the origin is determined to be business related rather than personal, the Gilmore origin test ceases to be useful. The Woodward origin test is arguably not relevant to $B$ 's case. $B$ did not incur these particular expenses in the "process of acquisition" of a new patent interest. Rather, the legal fees were paid out to establish his already existing rights in the patent and to accumulated income, rights he had acquired in the past through his efforts in the joint development of the patent with $A$. Nevertheless, courts following Anchor Coupling and Reed would now ask what was the "real" origin of $B$ 's litigation: the recovery of past royalties (deductible expense) or the declaration of a partnership interest in the patent (capital expenditure).

One may well ask how this differs from determining $B$ 's primary purpose in instituting the suit. ${ }^{118}$ The court or Service still will be

116 See text accompanying notes 36-37 supra.

117 See note 48 supra \& accompanying text.

118 The language of Anchor Coupling Co. v. United States, 427 F.2d 429 (7th Cir. 1970), cert. denied, 401 U.S. 908 (1971) and Reed v. Commissioner, 55 T.C. 32 (1970) demonstrates the similarity of the two tests. In Anchor Coupling, the court held that "the origin and nature of the claim ... directly concerns Anchor's capital assets." 427 F.2d at 433 . In Reed, the Tax Court found that "the origin is directly related to the capital asset underlying the partnership agreement." 55 T.C. at 42 . Such language bears a suspicious resemblance to the expressions of the courts when using the primary purpose test. The courts again have the freedom to determine the primary, dominant, or direct origin despite the Supreme Court's efforts to curb such subjectivism. 
involved in an inquiry of causality whether denominated "origin" or "purpose." Although the latter may initially appear more subjective because individual intent must be ascertained, the difference is more semantic than real. In determining the Woodward-type origin, the court must be influenced by whatever purpose the taxpayer seems to have been furthering, in other words whether acquisition of income or title was the predominant motivation. If a court refuses to inquire into the taxpayer's intent and limits itself to so-called objective facts to determine which element was the more likely source of the litigation, the court may be left with such questionable factors as relative monetary values of the two potential elements of recovery, the current financial status of the taxpayer, the comparative likelihood of prevailing on the merits of each claim, or a descriptive determination of what most people would be seeking. In this inquiry, however, each question appears aimed at a determination of what must have been the taxpayer's purpose, albeit based on supposedly objective factors and without any inquiry into individual motivation.

Newark Morning Ledger Co. v. United States, ${ }^{119}$ a recent Third Gircuit case, illustrates these observations. The taxpayer-newspaper had previously acquired a beneficial, controlling interest in the stock of another newspaper. The Morning Ledger instituted a derivative action as shareholder, alleging malfeasance by the management of the acquired newspaper. It later deducted its legal fees as business expenses under section 162. The Third Circuit adopted the Woodward origin test ${ }^{120}$ and stated: "In announcing the 'origin and nature' test, the Supreme Court limited the category of controlling facts to 'objective' rather than 'subjective' ones." 121 Concluding that "[i]ntent or motive is irrelevant under the origin of the claim test," ${ }^{122}$ this court found that "[ $\left.t\right]$ he origin of the litigation was to prevent destruction of assets rather than gain benefits." ${ }^{123}$ The difference between this and the determination that the purpose of the litigation was to prevent destruction of assets rather than gain benefits is negligible. Very little has been gained by the replacement of the "subjective" primary purpose test by the "objective" origin test, other than the sterile satisfaction of new descriptive terms.

119539 F.2d 929 (3d Cir. 1976).

120 Id. 934.

121 Id.

122 Id. 935.

123 Id. 934. 
The greatest danger of the Woodward origin test, however, inheres in the ordinal connotation of the word "origin." Because origin suggests source or first, ${ }^{124}$ the court may be led to a but-for determination that will deny the deduction in most instances. In the hypothetical situation, the court could find that but for the capital asset, the patent, that forms the basis of the controversy, no royalties would exist. ${ }^{125}$ The origin test leads the court to that type of decisionmaking because the inquiry seems to consist of determining the element that preceded and formed the basis of the controversy, thereby originating the suit. In a mixed title and income suit, of course, the solution will be nondeductibility because title must be established before right to the income from the asset can be established. The determination of deductibility becomes mechanical and very certain: because perfection of title must precede right to income, the capital element will overpower the ordinary element. ${ }^{\mathbf{1 2 6}}$

124 Origin is defined as "rise, beginning, or derivation from a source" and "primary source or cause." WEBSTER's THIRD NEw INT'L Dictronary 1591 (unabr. 1966).

125 In Munn v. United States, 455 F.2d 1028 (Ct. Cl. 1972), taxpayer, the income beneficiary of a trust fund, incurred legal fees to force a reassessment of extraordinary income payable to him after the trust sold various assets. The taxpayer argued that his expenses were incurred for the production of income and hence were deductible under section 212. Citing Woodward and Hilton Hotels, the court, however, held the expenses nondeductible:

$[H]$ ere there was the sale of a capital asset. This factor leads to our opinion that for whatever reason plaintiff felt he was incurring the expenses ... they cannot be divorced from the sale of the capital assets. It cannot be disputed that without the sale of stock there would have been no reason to instigate the legal action for collection of the proceeds of that sale.

Id. 1033. The court here employed the dangerous "but for" test that clearly proves too much and that would eclipse the section 212 deduction because virtually all income can. be related directly or indirectly to a capital asset. The court might as easily have concluded that the origin of the taxpayer's litigation was the determination of the correct amount of income due him under the trust and thus ruled in favor of the deductibility of the expenses. The result in Munn is most probably correct, however, because the underlying transactions, the sale of stock and the distribution of income resulted in capital gain to the recipient. See I.R.C. $\$ 662$ (b) (retention of tax character of items distributed to beneficiaries of trusts). Even though capital gains constitute current income to the recipient, expenses directly related to the sale of assets are treated as adjustments to the basis or sales price rather than as deductible expenses. See Commissioner v. Doering, 335 F.2d 738, 741 (2d Cir. 1964). The methodology of the case-the "but for" analysis-must be eschewed, however, for the section 212 deduction would virtually disappear.

126 The Fifth Circuit recently borrowed the origin test from the $\$ \S 162,212$ context to determine deductibility of legal fees as a loss under $\$ 165$ (c)(2). Meyer v. Commissioner, 547 F.2d 943 (5th Cir. 1977). In Meyer, taxpayers entered into five different purchase orders through their broker for stock that was never delivered. They instituted suit to rescind the order and to obtain return of their advances and received in settlement some cash and stock. In ruling under $\$ 165(c)(2)$ on the 
Such a mechanical solution is inherently inequitable and theoretically unsound. First, it is unlikely that $B$ has one motive or that the litigation has one origin so predominant that identification of expenses with that single motive or origin reflects reality. In this sense, both the primary purpose and the origin of the claim test suffer from the same defect. More importantly, however, since both tests yield all or nothing results they fail to accommodate the theoretical basis of the capital-ordinary distinction: temporal matching. The mechanical all or nothing rule might be supportable if taxpayers and their advisors could thereby predict a reliable result. Similarly, the tests might be justified because they promoted ease in decisionmaking by the Service and the courts. Certainty, reliability, and administrative feasibility might justifiably be traded for a tolerable amount of inequity. The cases discussed abundantly evidence, however, that neither certainty nor administrability has been achieved under either test. Furthermore, no amount of certainty, would support the evisceration of sections 162 and 212 were the but-for test universally adopted. The observer is forced to conclude that (I) the tests unrealistically assume that expenditures have single, clearly identifiable, dominant bases, (2) the results are inconsistent with the policy of temporal matching that underlies the capital-ordinary distinction, and (3) the positive attributes of a mechanical rule that might justify the inequitable or incorrect results have not been realized.

deductibility of the legal fees incurred, the court purportedly applied the Woodward and Gilmore decisions and resulting origin of the claim test, id. 947 , but actually must have been employing a hybrid "original purpose" test. The court indicated that the factual determination that taxpayers had entered the original stock transaction for profit rendered the later expenses deductible under the origin test. Id. It rejected the Commissioner's argument that the suit was instituted to recover property and hence that the expenditures were capital and nondeductible. The court articulated the ground of its holding as follows: "The purpose of the expenditure for legal fees was to rescind a contract for stock and to recover the purchase price." Id. 948 (emphasis supplied).

This combination of purpose and origin demonstrates the difficulty courts continue to experience in determining the correct standard for decision in the mixed issue suit. In Meyer, the outcome depended on the court's choice of origin-the original profit-seeking transaction as argued by the taxpayer or the more proximate suit to recover property as argued by the Commissioner. After defining the origin so that the expenses were deductible, however, the court disallowed a portion of the expenses and required capitalization to the extent that the recovery consisted of stock. Id. Theoretically, the origin test accords no relevance to the consequences of a particular suit and hence the court's reasoning-although leading to an attractive result-seems unsound.

In passing it may be noted that the court was understandably uncomfortable with the Commissioner's argument in favor of capitalizing all the fees. Even if the origin of the suit was to recover property, that property, cash, was not capital in nature. See id. 947, 948. See also note 127 infra. 


\section{The Alternative: Allocation Between the Capital and Ordinary Elements}

In litigation indirectly involving title or in which title is not the sole issue, allocation of expenditures between the deductibleordinary and nondeductible-capital categories would promote equity and the relevant policy of temporal matching as well. In the hypothetical, $B$ would be allowed to deduct against the current royalty income the expenses properly allocable to its collection, whereas he would be required to capitalize the portion attributable to the declaration of his interest in the patent. ${ }^{127}$ Allocation permits a court to adopt a common sense approach and recognize for all purposes that the suit consists of a mixture of capital and ordinary elements. Furthermore, it avoids the absurd differentiation that heretofore existed between expenses of a single suit with two elements and the combined expenses of two suits on the same underlying subject matter but split by remedy or complaint. That would occur, for example, if $B$ filed suit first to perfect title to the patent and thereafter to collect accrued royalties. In such a situation, the courts have been more than willing to characterize the expenses of the first suit as nondeductible capital expenditures and those of the second as deductible expenses. ${ }^{128}$

127 A would similarly deduct his expenses attributable to litigation of the royalties and capitalize those attributable to the issue of title to the patent into the basis of his one-half interest. A might prefer capital loss treatment in regard to the latter expenses. See I.R.C. $\$ 165(\mathrm{f})$. He would have to explain, however, how he managed to "exchange" an interest in the patent which in the court's determination he never owned. A similar issue is presented as to what would be the proper treatment of $B$ 's expenses if he lost both on the royalty and patent issues. Given the business origin of the litigation, presumably $B$ would argue that the expenses are entirely deductible under $\$ 162$. The Service will wish to argue that at best $B$ is entitled to capital loss treatment, but then it will be faced with the task of explaining the whereabouts of the capital asset upon the exchange of which the loss was incurred. Cf. Meyer v. Commissioner, 547 F.2d 943 (5th, Cir. 1977), discussed at note 126 supra.

128 In Boagni v. Commissioner, 59 T.C. 708 (1973), taxpayer incurred legal expenses in two separate proceedings: (1) a declaratory judgment action in which members of his family sought a determination that they owned twenty-nine percent of an overriding royalty interest and (2) a concursus proceeding in which the oil company sought directions for the disposition of the proceeds of the oil produced from the property in issue, $i d$. 710. The court characterized the original suit as defense of title and the concursus proceeding as a suit for the collection of accumulated royalties and allocated the legal expenses between the two. Id. 715. See also Usry v. Price, 325 F.2d 657 (5th Cir. 1963) (First suit adjudicated title to oil producing property, second dealt with royalties from same land but different wells. Taxpayers successfully pleaded res judicata as to title and asserted unqualified right to royalties. Legal expenses of second suit entirely deductible.). A rule of law which differentiates on the basis of the form in which property and income are recovered and yet fails to recognize the same distinctions when a single suit is brought combining the two cannot be sound. Such a rule encourages resort to multiple lawsuits and promotes inefficient use of judicial resources. 
The major problem presented by allocation is one of administrability. Because a court would be required to distinguish the existence of the capital and ordinary elements in order to apply either the primary purpose or origin test, the added complication lies entirely in the process of allocating the expenses themselves. This complication must be balanced against the dysfunction of the inquiry under the purpose or origin tests: its failure to effectuate the temporal matching policy central to the capital-ordinary distinction. Furthermore, the courts and the Internal Revenue Service do have experience in allocating expenses in certain limited areas. Under each of the tests and in differing situations, the courts have sometimes been amenable to allocation of the expenses among the identifiable categories. The courts generally have not stated why allocation is appropriate in the particular instance, but from the language of the various opinions it appears that allocation will be allowed when two distinct and equally important purposes or origins coexist. ${ }^{129}$ Allocation, however, should be the rule and not simply an exception when more than one strong motive or true origin is discovered. The expenses should be apportioned between deductible and nondeductible categories in any controversy in which capital and ordinary elements are distinguishable (unless one is clearly de minimus ${ }^{130}$ ).

Courts have apportioned expenses between capital and ordinary categories in cases which involve oil- or mineral-producing property and royalties, ${ }^{131}$ patent infringement and royalties, ${ }^{132}$ trademark infringement and unfair competition,, ${ }^{133}$ stock and accumulated

129 See, e.g., Singer v. Commissioner, 34 Tax Ct. Mem. Dec. 337, 348 (1975) ("the attorney's fee was paid for a dual purpose"); Thomas E. Arnett, 31 T.C. 320, 335 (1958) ("Arnett had two purposes in instituting the litigation here in question: (1) To quiet title and (2) to collect income; and that neither purpose was predominant."). See generally Rust-Oleum Corp. v. United States, 280 F. Supp. 796 (N.D. Ill. 1967).

130 See, e.g., Kozak v. Commissioner, 30 Tax Ct. Mem. Dec. 717 (1971).

131 Estate of Morgan v. Commissioner, 332 F.2d 144 (5th Cir. 1964); Brown v. United States, 70-2 U.S. Tax Cas. $\llbracket 9501$ (N.D. Tex. 1970); Boagni v. Commissioner, 59 T.C. 708 (1973); Vest v. Commissioner, 57 T.C. 128 (1971), rev'd in part, aff'd in part on other grounds, 481 F.2d 238 (5th Cir.), cert. denied, 414 U.S. 1092 (1973); Thomas E. Arnett, 31 T.C. 320 (1958); James Petroleum Corp., 24 T.C. 509 (1955), aff'd, 238 F.2d 678 (2d Cir. 1956), cert. denied, 353 U.S. 910 (1957). Cf. Usry v. Price, 325 F.2d 657 (5th Cir. 1963) (deductibility of fees in second suit upheld when based on determination of title in previous suit). But see Kasey v. Commissioner, 54 T.C. 1642 (1970), aff'd, 457 F.2d 369 (9th Cir.), cert. denied, 409 U.S. 869 (1972) (determination of title primary issue).

132 William A. Falls, 7 T.C. 66 (1946). But see Safety Tube Corp. v. Commissioner, 168 F.2d 787 (6th Cir. 1948) (right to asset gist of controversy).

133 Rust-Oleum Corp. v. United States, 280 F. Supp. 796 (N.D. Ill. 1967). This unique suit and differentiation should not be confused with those cases that consistently hold that legal expenses incurred in a trademark infringement suit are 
interest or dividends, ${ }^{134}$ employment related stock repurchase agreement and bonus, ${ }^{135}$ derivative action against management to recover illegally paid bonus and fraudulently conveyed stock, ${ }^{136}$ partnership interest and an accounting, ${ }^{137}$ divestiture action and defense of antitrust litigation, ${ }^{138}$ defense of title and preservation of value of stock, ${ }^{139}$ employment related stock repurchase agreement and settlement of negligence claim against employer, ${ }^{140}$ and title to rent producing property and rental income. ${ }^{141}$

The last example is especially interesting because the Regulations under section 212 explicitly provide for this type of allocation: "Attorneys' fees paid in a suit to quiet title to lands are not deductible; but if the suit is also to collect accrued rents thereon, that portion of such fees is deductible which is properly allocable to the services rendered in collecting such rents." ${ }^{142}$ Nothing inherent in the nature of rental property and accrued rents, however, suggests that the same allocation should not generally be accorded to other dual element controversies. Indeed, the Regulation under section 212 that treats the nondeductibility of capital expenditures contains a cryptic parenthetical statement that could arguably be construed as authority for allocation between capital and income

nondeductible capital expenditures. Danskin, Inc. v. Commissioner, 331 F.2d 360, 361 (2d Cir. 1964) ("The financial gain which petitioner realized from these legaI proceedings, through the enhancement of the value of its registered trademark, is an increment of a sort which will endure for many years to come."). Accord, Medco Prod. Co. v. Commissioner, 523 F.2d 137 (10th Cir, 1975); Georator Corp. v. United States, 485 F.2d 283 (4th Cir. 1973), cert. denied, 417 U.S. 945 (1974); Buddy Schoellkopf Prod., Inc. v. Commissioner, 65 T.C. 640 (1975).

134 Spangler v. Commissioner, 323 F.2d 913 (9th Cir. 1963); Helvering v. Stormfeltz, 142 F.2d 982 (8th Cir. 1944).

135 Joseph Frank, 22 T.C. 945 (1954), affd, 226 F.2d 600 (6th Cir. 1955).

136 Larchfield Corp. v. United States, 373 F.2d 159 (2d Cir. 1966). This case raises the interesting point that although legal fees paid on its own behalf would be nondeductible to the corporation, they do not have the same character when made by a corporation pursuant to a contractual arrangement to indemnify an employee. "Payment of legal fees under such a by-law has been reasonably characterized as a fringe benefit necessary to induce officers and directors to serve, deductible in any event to the corporation as reasonable compensation." Id. 167 (quoting McDonald, supra note 4, at 191-92).

137 Estate of Morgan v. Commissioner, 332 F.2d 144 (5th Cir. 1964); cf. Reed v. Commissioner, 55 T.C. 32 (1970) (taxpayer provided no basis upon which allocation could be made). But see Rassenfoss v. Commissioner, 158 F.2d 764 (7the Cir. 1946) (accounting primary purpose). 1970).

138 E.I. duPont de Nemours \& Co. v. United States, 432 F.2d 1052 (3d Cir.

139 Singer v. Commissioner, 34 Tax Ct. Mem. Dec. 337 (1975).

140 Eisler v. Commissioner, 59 T.C. 634 (1973).

141 Daniel S.W. Kelly, 23 T.C. 682 (1955), aff'd, 228 F.2d 512 (7th Cir. 1956).

142 Treas. Reg. $\$ 1.212-1(k)(1957)$. 
elements generally: "Expenses paid or incurred in defending or perfecting title to property, [or] in recovering property (other than investment property and amounts of income which, if and when recovered, must be included in gross income) . . . constitute a part of the cost of the property and are not deductible expenses." 143 One commentator has noted that this parenthetical "seems to have passed completely without judicial interpretation." 144

The Supreme Court has indicated its approval of apportioning expenses between business and personal categories ${ }^{145}$ and courts have allocated expenses between those categories in cases which involved alleged malfeasance with respect to personal residence and financial advising and fiduciary duties, ${ }^{146}$ relationship with brother and partnership accounting, ${ }^{147}$ annulled marriage and dividend and interest income, ${ }^{148}$ and especially divorce and alimony. ${ }^{140}$ The latter constitutes an important exception to Gilmore and its companion United States $v$. Patrick ${ }^{150}$ but "relates solely to expenses incurred by the wife for the production or collection of amounts 'includible in gross income under section 71,' which deals with the taxability of alimony and similar amounts received by a wife as separate maintenance or support in connection with the marital relationship." 151 The allocation between legal expenses of divorce, nondeductible as personal expenses, and those related to the collection or production of includible alimony is expressly provided for in the Regulations:

[T] $T$ he part of an attorney's fee and the part of the other costs paid in connection with a divorce, legal separation, written separation agreement, or a decree for support, which are properly attributable to the production or col-

${ }^{143}$ Id. (emphasis supplied).

$144 \mathrm{McD}$ onald, supra note 4 , at 186 n.179. He also concludes that the only grammatical interpretation of the Regulation would also mean that expenses of recovering investment property are deductible rather than additions to basis. Id. Such a treatment, however, would be against the substantial weight of judicial interpretation.

145 Higgins v. Commissioner, 312 U.S. 212, 218 (1941).

146 Ditmars v. Commissioner, 302 F.2d 481 (2d Cir. 1962).

147 Buder v. United States, 221 F. Supp. 425 (E.D. Mo. 1963).

148 Kozak v. Commissioner, 30 Tax Ct. Mem. Dec. 717 (1971).

149 Howard v. Commissioner, 34 Tax Ct. Mem. Dec. 751 (1975); Mirsky v. Commissioner, 56 T.C. 664 (1971); Porter v. Commissioner, 25 Tax Ct. Mem. Dec. 448 (1966), aff'd on other grounds, 388 F.2d 670 (6th Cir. 1968); Ruth K. Wild, 42 T.C. 706 (1964).

150372 U.S. 53 (1963).

151 Gerald G. Wolfson, 47 T.C. 290, 294 (1966). 
lection of amounts includible in gross income under section 71 are deductible by the wife under section $212 .{ }^{152}$

In this instance the differing treatment for expenditures that result in current income is drawn by reference to section 71 which requires inclusion of alimony in income under certain circumstances. ${ }^{153}$ Again it is difficult to understand why the divorce and alimony dichotomy is any more conducive to allocation than any other dual purpose or origin controversy.

The courts and Service have treated the deductibility of a portion of legal expenses properly allocable to the recovery of taxable as opposed to nontaxable income as a distinct area in which apportionment of the expenses is unquestioned.154 The Regulations under section 265 which disallows any otherwise available deduction if the expenditure relates to tax-exempt income ${ }^{155}$ specifically provide for allocation between the two categories:

Expenses and amounts otherwise allowable which are directly allocable to any class or classes of exempt income shall be allocated thereto; and expenses and amounts directly allocable to any class or classes of nonexempt income shall be allocated thereto. If an expense or amount otherwise allowable is indirectly allocable to both a class of nonexempt income and a class of exempt income, a reasonable proportion thereof determined in the light of all the facts and circumstances in each case shall be allocated to each. ${ }^{186}$

Similarly, the courts and Service allow deduction of legal expenses properly allocable to tax advice when included with other expenses that are nondeductible. ${ }^{157}$

152 Treas. Reg. $\$ 1.262-1(b)(7)(1958)$.

153 I.R.C. $\$ 71$.

154 Mary Tighe, 33 T.C. 557 (1959); William H. Jamison, 8 T.C. 173 (1947); Mary K. Ellis, 6 Tax Ct. Mem. Dec. 662 (1947); Edward Mallinckrodt, Jr., 2 T.C. 1128 (1943), aff'd, 146 F.2d 1 (8th Cir.), cert. denied, 324 U.S. 871 (1945). Cf. Tucker v. Commissioner, 322 F.2d 86 (2d Cir. 1963) (similar allocation of trust expenses between tax-exempt and taxable income under I.R.C. \$652).

155 I.R.C. $\$ 265(2)$.

156 Treas. Reg. $\$ 1.265-1$ (c) (1958).

157 Suter v. United States, 316 F. Supp. 834 (S.D.N.Y. 1970) (capital expenditures, personal expense and tax advice expense); Munn v. United States, 455 F.2d 1028 (Ct. Cl. 1972) (capital expenditure and tax advice expense); Merians v. Commissioner, 60 T.C. 187 (1973) (estate planning expenditure and tax advice expense). See also Rev. Rul. 545, 1972-2 C.B. 179 (divorce expenses and tax advice expense). 
Allocation effectuates the matching policy permeating the expense deduction and disallowance provisions of the Code. A substantial number of judicial rulings and tax regulations support such allocation in specific instances and demonstrate the capacity of the judiciary and administrative bodies to undertake the apportionment process. Three methods of allocation are possible.

The first procedure places the burden on the taxpayer's attorney to record as accurately as possible the actual time spent on the separable aspects of a particular controversy..$^{15 s}$ This procedure is attractive because the majority of attorneys already keep fairly detailed records of time expended. It is unlikely, however, that the records are sufficiently categorized beyond time expended for a particular client on a particular matter to facilitate a determination, for example, of the proportion of a three hour meeting actually spent discussing the income issue or the title issue. If feasible, however, such a method provides a concrete basis for allocation. Furthermore, the attorney should be expert in determining the division of his fees among the several elements. The procedure does have the drawback, however, of placing the attorney in a position of potential ethical conflict. As a practical matter the client will desire a maximum deduction and the attorney will desire to further his client's interests consistent with the Professional Code of Ethics and the law.

The second method allocates expenses on the assumption that fees were incurred in proportion to the separate classes of recovery. Under this system, in a mixed capital-ordinary situation, the entire expense would be multiplied by a fraction, the numerator of which is the amount recovered in a particular class and the denominator of which is the total amount recovered. For example in the hypothetical, $B$ 's deductible expenses would equal $\$ 4,000$ (total legal

158 The Internal Revenue Service specifically approved this method to separate expenses for advice regarding the tax consequences incident to divorce from the expenses of divorce advice itself in Revenue Ruling 72-545, 1972-2 C.B. 179. The ruling contains two examples of the "reasonable basis" required for allocation and deduction of expenses of tax advice: (1) A law firm handled certain nontax divorcerelated matters in addition to tax matters incident to the divorce. The tax problems are handled exclusively by the firm's tax department. The statement for the firm's services breaks down the fee between time of the tax department and other time. (2) A firm represents the taxpayer in connection with all matters pertaining to a divorce. Although apparently not segregated by department, the firm allocates the fee between the tax and nontax matters 'based primarily on the amount of attorney's time attributable to each, the fee customarily charged in the locality for similar services, and the results obtained in the divorce negotiations." Id.

The ruling contains a third example that involves no true allocation: A law firm limiting its practice to matters involving state and federal taxation advises the taxpayer of the federal tax consequences of a proposed property settlement. All the expenses are deductible. Id. 
fees) times $\$ 75,000$ (royalties recovered) divided by $\$ 300,000$ (total amount recovered) or $\$ 1,000$. The remainder or $\$ 3,000$ would be an addition to the patent's basis. In Helvering $v$. Stormfeltz, ${ }^{153}$ the court stated: "Such allocation attributes to each of the separate classes of recovery its proportionate part of the total expense and would seem to be a rational method of distribution of expense." 160

Courts have adopted this method in situations involving recovery of stock and dividend income, ${ }^{161}$ enforceability of stock repurchase agreement and settlement of negligence claim, ${ }^{162}$ recovery of taxable and nontaxable income, ${ }^{163}$ recovery of patent and past royalties, ${ }^{164}$ and recovery of rent-producing property and rent. ${ }^{165}$ In fact the recovery ratio seems to be the most widely adopted method for allocating expenses. The procedure can be criticized as arbitrary and inaccurate, for generally there is no indication in such cases that the expenditures were actually made in the resulting proportions. ${ }^{166}$ Furthermore, the procedure will be useful only where there is recovery. Finally, even if recovery is had, the judgment may not itself contain a separate breakdown of the recovery actually achieved with respect to each item. For example, $B$ might have obtained a judgment granting him a one-half interest in the patent and $\$ 75,000$ in accrued royalties. In order to use the recovery ratio procedure, $B$ must estimate the value of his half interest in the patent. In that situation $B$ probably has no particular ex: pertise in this area compared to the lawyer who is expert in judging the value of his services. $B$ would probably require an outside appraisal, but the cost may prove prohibitive in relation to the deduction sought. In those situations in which the value of the several elements of recovery are readily ascertainable, however, the superior administrability of this method over the first outweighs any potential arbitrariness or inaccuracy. It should be the pre-

159142 F.2d 982 (8th Cir. 1944).

$160 I d .985$.

161 Spangler v. Commissioner, 323 F.2d 913 (9th Cir. 1963); Helvering v. Stormfeltz, 142 F.2d 982 (8th Cir. 1944).

162 Eisler v. Commissioner, 59 T.C. 634 (1973).

163 Mary Tighe, 33 T.C. 557 (1959); Edward Mallinckrodt, Jr., 2 T.C. 1128 (1943), aff'd, 146 F.2d I (8th Cir.), cert. denied, 324 U.S. 871 (1945).

164 William A. Falls, 7 T.C. 66 (1946).

165 Daniel S.W. Kelly, 23 T.C. 682 (1955), affd, 228 F.2d 512 (7th Cir. 1956).

166 In fact the procedure is often used because of a lack of evidence as to actual expenditures. See, e.g., Daniel S.W. Kelly, 23 T.C. 682 (1955), aff'd, 228 F.2d 512 (7th Cir. 1956); Edward Mallinckrodt, Jr., 2 T.C. 1128 (1943), aff'd, 146 F.2d I (8th Cir.), cert. denied, 324 U.S. 871 (1945). 
ferred method and the existence of two measurable elements should create a presumption that the resulting ratio is the correct measure.

If the necessary values are not available, however, the third procedure would attempt to accommodate as closely as possible all the facts and circumstances of a particular multi-faceted suit. As one court has stated:

$[W]$ e must look to the issues involved, the nature and objectives of the suit in which the expenditures were made, the defenses asserted, the purpose for which the claimed deductions were expended, the background of the litigation, and all facts pertaining to the entire controversy out of which the disputed expenses arose. ${ }^{167}$

At this point, the same considerations encountered in the discussions of the primary purpose and origin tests resurface. It is relevant at this point to determine the relative weights that the taxpayer may have accorded the elements of the suit and to determine which of several origins may have been the most fundamental. The observations of Judge Learned Hand in Cohan $v$. Commissioner, ${ }^{188}$ are apropos:

The Board refused to allow him any part of [his entertainment expenses], on the ground that it was impossible to tell how much he had in fact spent, in the absence of any item or details. The question is how far this refusal is justified, in view of the finding that he had spent much and that the sums were allowable expenses. Absolute certainty in such matters is usually impossible and is not necessary; the Board should make as close an approximation as it can, bearing heavily if it chooses upon the taxpayer whose inexactitude is of his own making. ${ }^{169}$

Utilized in myriad situations to allow deductions that would otherwise be denied because of a failure of strict proof, 170 the Cohan doctrine has frequently been invoked to allocate legal fees between two categories of deductible and nondeductible expenses. ${ }^{171}$

107 Estate of Morgan v. Commissioner, 332 F.2d 144, 151 (5th Cir. 1964). Accord, Buder v. United States, 221 F. Supp. 425 (E.D. Mo. 1963).

16839 F 2d 540 (2d Cir. 1930).

160 Id. 543-44.

170 See cases collected in $4 \mathrm{~A}$ Mertens, supra note $2, \$ 25.04$.

171 Brown v. United States, 70-2 U.S. Tax Cas. I 9501 (N.D. Tex. 1970); Buddy Schoellkopf Prod., Inc. v. Commissioner, 65 T.C. 640 (1975); Merians v. Commissioner, 60 T.C. 187 (1973); Vest v. Commissioner, 57 T.C. 128 (1971), 
Usually in litigation indirectly involving title some evidence will exist to enable the court to make a reasoned apportionment of the expenses. In contrast to the Cohan case, the inexactitude will not be of the taxpayer's own making, but will stem from the impossibility of actual measure. In defense of title cases, therefore, the courts should not use a presumption against the taxpayer. The goal is a reasonable approximation of the actual expenses incurred with respect to each element:

We recognize that a rough approximation is all that can be expected. The records of Ditmars' attorneys may contain material that will assist in the allocation of the counsel fees, and opinion evidence may have to be taken as to the relative gravity of the trustee's charges-unless, indeed, the parties should avail themselves of a less scientific but probably more satisfactory method of disposition. ${ }^{172}$

In situations in which clear and convincing proof is not available and in which the recovery ratio method cannot be used, the basic policy of temporal matching militates in favor of a reasonable allocation based on as many of the surrounding facts and circumstances as can be ascertained. Although such a method can be criticized as engendering disputes between taxpayers and the Service, the record under the primary purpose and origin of the claim tests shows that the sacrifice of equity and accuracy has not achieved certainty under the revenue laws. The alternative of allocation has the virtue of giving truer expression to the essential matching policy of the capital-ordinary distinction.

rev'd in part, aff'd in part on other grounds, 481 F.2d 238 (5th Cir.), cert. denied, 414 U.S. 1092 (1973); Thomas E. Amett, 31 T.C. 320 (1958); James Petroleum Corp., 24 T.C. 509 (1955), aff'd on other grounds, 238 F.2d 678 (2d Cir. 1956), cert. denied, 353 U.S. 910 (1957); Daniel S.W. Kelly, 23 T.C. 682 (1955), aff'd, 228 F.2d 512 (7th Cir. 1956).

172 Ditmars v. Commissioner, 302 F.2d 481, 488-89 (2d Cir. 1962). 